\title{
The role of collaborative research in learning to incorporate values of the public in social-ecological system governance: case study of bushfire risk planning
}

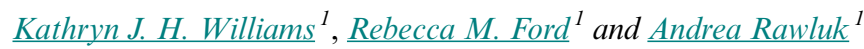

ABSTRACT. Values of the public are a key and dynamic component of bushfire governance SES. Learning to work with these values is a significant challenge for government and environmental managers and an important aspect of policy transition in many contexts. During such transitions, collaborative research can play a key role in social learning, but this may be particularly challenging for agencies with dominant expertise in technical and ecological domains. We examined how collaborative research supported social learning to incorporate values of the public in bushfire governance in the State of Victoria, Australia. Following disruption of a major bushfire, new policy directions were established, including greater attention to expectations and participation of communities in bushfire management. Among other actions, the state environmental agency supported this policy transition by establishing a 3-year research collaboration to better understand and incorporate values of the public in their decision making. As both participants and observers of this research, we analyzed publications, unpublished internal reports, and notes from meetings and workshops to identify how the collaborative research facilitated and constrained learning. Analysis revealed how collaborative research presents interruptions in the form of questioning of plans and routines (including of researchers), joint concept development, collection and sharing of new information, tensions within the research collaboration, idea generation building on research insights, and action research to develop new tools or frameworks. These forms of disruption operated in different ways, involving different groups of actors, levels of collaboration, and opportunities for feedback, and these in turn had implications for the forms of learning that occurred. Collaborative research also identified constraints to learning that, in some instances, set the stage for further learning, for example through capacity building and further research.

Key Words: adaptive governance; policy transition; research collaboration; social learning; values; wildfire

\section{INTRODUCTION}

Over a sustained period, researchers have called for better incorporation of values of communities and the broader public in environmental and social-ecological systems (SES) governance (e.g., Bengston 1994, Thacher and Rein 2004). In response, some environmental agencies seek to understand and more explicitly manage values in decision making (Ford et al. 2019). Guidance for achieving this is increasing, with research suggesting how values might be conceptualized and observed (e.g., Jones et al. 2016, van Riper et al. 2018) and outlining approaches for working with values (e.g., O'Brien 2003, Gregory et al. 2012, Ives and Kendal 2014, Artelle et al. 2018). Given the diversity of contexts in which values are relevant to SES governance (see O'Brien 2003 for examples), it is unsurprising that there is no single "off the shelf" solution. Considerable learning is necessary as agencies determine how best to understand and manage values in particular decision settings. Collaborative research offers a form of social learning that may be especially useful during the early stages of policy transition, including shifts to incorporate values in decision making, but comes with many challenges (van Herk et al. 2011). Drawing on collaborative research to learn how to manage values may be particularly challenging for environmental agencies dominated by technical-scientific expertise as values are often viewed as insufficiently "objective" or "scientific" (Ives and Kendal 2014). In this context, we analyze a 3-year collaborative research program on values of the public in bushfire governance to understand how collaborative research can support learning about working with values in SES governance.
Values and Bushfire Adaptive Governance

We approach bushfire governance as part of dynamic SES comprising the irreducible components of and relationships between (1) ecological properties such as global and regional climate, vegetation, and fuel in the landscape and (2) social properties such as international and national risk management frameworks, communities at risk and their knowledge, and values, management practices, and financial expenditure (see Fig. 1, and also Steelman 2016). The institutions, community groups, businesses, and individuals involved in an SES both shape and are shaped by change in all parts of the system.

Values are key components of SES but have been conceptualized and assessed in multiple ways. Natural sciences typically define values as biophysical properties of ecological systems (Reser and Bentrupperbäumer 2005). In contrast, social scientists generally consider values primarily as cognitive components of the SES representing ideas of preferred states of being or ways of acting (Jones et al. 2016). Within this approach, ecological and social attributes of a system become valued as people relate to them through their held values, for example, through having needs met (e.g., through ecosystem services) and broader principles for action (such as intrinsic and cultural values) (Rawluk et al. 2019). Social science points to the importance of both individual values and collective values, recognizing the potential for value conflicts in SES governance (van Riper et al. 2018). Values are also understood to change and be changed by other components of the SES, although values in the surrounding culture may be critical in maintaining stability of systems (Manfredo et al. 2017). 
Considered through this lens (summarized in Fig. 2), understanding and working with values require new forms of SES governance, including social analysis and community-based decision making (O'Brien 2003, Ives and Kendal 2014, Artelle et al. 2018).

Fig. 1. Examples of components of a bushfire management SES. Fast- and slow-changing ecological and social properties can be observed acting and interacting in different combinations at multiple scales (adapted from Steelman 2016).

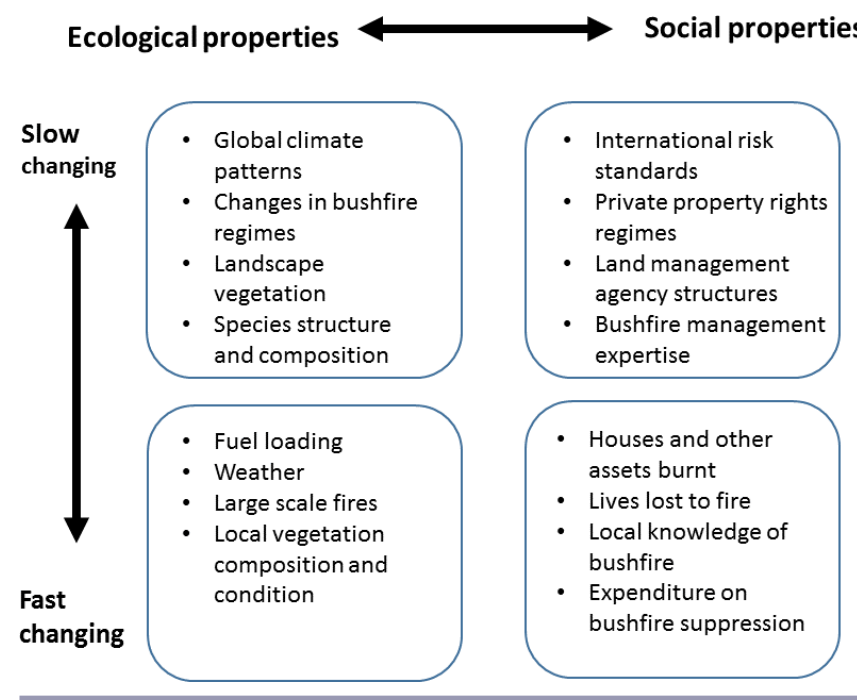

Fig. 2. Value-related components of a bushfire SES. Individual core values and broad shared values are cognitive and communicative properties of the system. Core and shared values normally change slowly, but dominant values can change fast at a local level where rapid population change occurs. Core values are applied to ecological and social properties of the system through a valuing process, resulting in valued attributes and entities of the system (Rawluk et al. 2017).

\section{Ecological properties}

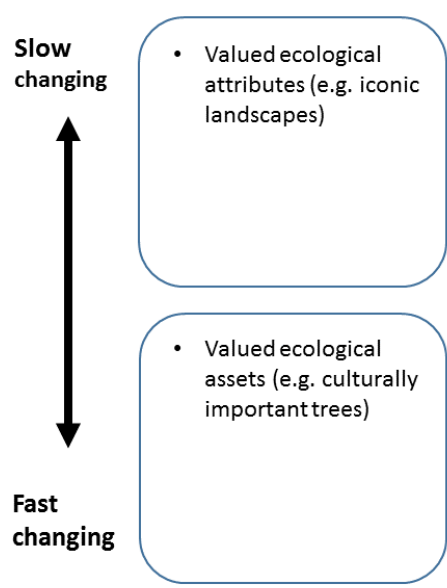

Social properties

- Broad shared values (e.g. individualism or collectivism)

- Individual core values (e.g. security, benevolence)

- Valued social attributes (e.g. cultural identity)

- Fast change in dominant social value can occur with rapid population change

- Valued social assets (e.g. homes, schools)
Efforts to understand and manage values in bushfire decision making can be understood as contributing to adaptative governance, that is, governance arrangements with capacity to navigate the inherent complexity and uncertainty of SES (Chaffin et al. 2014). Changes in the ways values are managed can be emergent (e.g., new patterns of organizational or individual action reflecting shifting societal values) or purposeful (e.g., deliberate policy changes in response to new understanding of values) (Stewart 2006). Adaptative governance is closely intertwined with learning, as emerging knowledge often plays constant catch-up to ongoing change (Armitage et al. 2008). During periods of deliberate policy transition - such as seeking to better manage values - the adaptive governance lens draws attention to how groups of actors learn together to change management.

\section{Learning to Manage Values in Bushfire Governance}

Although learning occurs at both individual and social levels (Armitage et al. 2008), we are primarily concerned with social learning within a collaboration between university researchers and agency staff responsible for developing new knowledge, frameworks, and practices for managing values. Social learning occurring within SES governance is conceptualized in terms of changes that occur in policy, structures, or routines within the regime (Pahl-Wostl 2009). In the context of this research, learning is therefore evident in changes within agency-level bushfire governance as well as within collaborative research arrangements.

Armitage et al. (2008) and Pahl-Wostl (2009) distinguish three forms of social learning. Single-loop learning involves incremental improvements to established routines. In the context of bushfire SES governance, this might include identifying ways to map social values for better inclusion within standard spatially based risk assessment processes (see, e.g., Tyrväinen et al. 2007). Double-loop learning involves reframing problems in ways that allow questioning of existing policy and assumptions. For example, previous research has identified how established practices and technologies constrain what values can be considered in decision making, for example, excluding values that cannot be spatially located or quantified (Neale 2016, Rawluk et al. 2019). Questioning these practices can be considered a form of double-loop learning (Pahl-Wostl 2009). Triple-loop learning involves transformation of governance norms and protocols. In SES management, this might be exemplified by the value-led approach to governance advocated by Artelle and colleagues (2018), which advocates incorporating values based in stewardship that could not be readily incorporated in spatially based risk assessment. Feedback plays a critical role in multiloop learning, with changes in governance, actors, environment, and technologies enabling further learning to occur (Pahl-Wostl 2009).

Social learning may be facilitated by disruptions to the SES or impeded by path dependencies and rules, which give stability to the system (Armitage et al. 2008). For example, Dwyer and Hardy (2015) observed how interpretation of major bushfires as "unprecedented" led to regime changes in the form of Royal Commissions into three Victorian bushfires. Drawing on Weick (1995), they identified how this triggered "sense making," a social process of creating shared understandings of events and how this in turn allowed social learning to occur. Opportunities for 
learning may however be constrained by technological infrastructure and "informal guiding principles" that create an internal logic that excludes some forms of change (Pahl-Wostl 2009). In the context of bushfire SES governance, traditional "command and control" paradigms have been observed to orient adaptation around risk reduction through excluding fire and educating communities, discouraging alternative forms of adaptation that might encourage living with fire as part of nature and dialog with communities about values and trade-off decisions (Bosomworth 2015).

\section{Research Collaboration and Learning to Work with Values}

Researchers have observed that collaborative research can play a key role in learning following SES disruption (van Herk et al. 2011), but research collaboration can itself be considered an interruption within SES governance. Collaboration is intrinsic to social learning and can take many forms, including top-down coordinated change, learning alliances, and communities of practice (Armitage et al. 2008, van Herk et al. 2011). van Herk and colleagues (2011) argued that collaborative research may play a particularly important role in early stages of policy transition by (1) supporting demonstration projects and stimulating niche innovations and (2) creating and using new networks of actors to influence policy and capacity building and create awareness. At this broad scale, collaborative research both responds to and sustains disruption, introducing new actors and technologies into decision and learning contexts. At a more intimate scale, Rawluk et al. (2020a) described how processes occurring within research collaborations (e.g., questioning, reflection, and data collection) interrupt and support new practical understandings of SES and enable learning in the form of changes to routines, values, and structures.

Acknowledging this potential, the challenges of collaborative research are also widely recognized (Raadgaver et al. 2012, Ayre et al. 2018). Ayre and colleagues (2018) highlight the importance of clear principles for collaboration, including all actors being involved in objective setting and codesign of plans for activities. van Herk and colleagues (2011) argue that connectedness and communicativeness of participants is critical to influencing learning beyond the immediate collaboration, whereas Raadgaver et al. (2012) advise that collaborative research should only occur where all involved stakeholders are keen to learn from the collaboration. Learning to work with values is likely to raise particular challenges for research collaborations that cross traditional divides between scientific-technical and social scientific knowledges (Ives and Kendal 2014). Values that can primarily be understood through qualitative methods and strategies for management that involve qualitative assessment or working closely with communities may be particularly challenging for environmental agencies steeped in ecological expertise (Ford et al. 2019).

\section{Aim and Scope}

In this paper, we examine social learning within a collaborative research process designed to understand and work more effectively with values of the public in a case of bushfire risk planning. We worked with staff from the Department of Environment, Land, Water and Planning (DELWP) in the State Government of Victoria, Australia over a 3-year period to help them understand values of the public in ways that are meaningful for bushfire planning and to develop ways to use this knowledge in their bushfire risk management. The analysis is guided by the question:

$$
\begin{aligned}
& \text { How does collaborative research support social learning } \\
& \text { to incorporate values of the public in bushfire governance? }
\end{aligned}
$$

\section{BUSHFIRE IN VICTORIA, AUSTRALIA: SES GOVERNANCE AND RESEARCH APPROACH}

Victoria, Australia, is a highly fire-prone environment, and fires of particular frequency and intensity are an integral process within many ecosystems (Williams et al. 2008). At the time of this research, fire was managed by multiple agencies, with DELWP leading management of public land and the Country Fire Authority and local government authorities supporting management of private land (Bosomworth 2015). Over many decades in Victoria, bushfire has been treated as a technoscientific emergency management problem, with community ignorance of risk to be addressed through education and garnering acceptance of agency decisions (Bosomworth 2015). Decision making on public land has typically been government led with limited scope for public participation (Ford et al. 2019). At the time this research was undertaken, expertise in DELWP was dominated by biophysical scientific knowledge of ecosystems, with preference for structured approaches to decision making based on quantitative and spatially explicit risk and ecological assessment (Neale 2016, Ford et al. 2019). The DELWP had a multilevel institutional structure to support bushfire management, including state-wide policy documents and objectives, centrally based planning staff that support and guide planning practice, and regionally based teams of planners and operational staff.

Bushfire agencies were navigating multiple changes in the Victorian bushfire SES. Many slow changes had occurred across the system over the previous few decades. Bushfire frequency, severity, and impact had increased, driven partly by ecological factors such climate change (Lindesay and Lindenmayer 2003). Periurban population growth brought greater risk and new societal expectations because new residents have little experience of managing their properties to reduce fire risk and higher expectations of government intervention than is common in rural areas (Muir et al. 2017). A rapid disruption occurred in 2009, when the Black Saturday fires killed 173 people, destroyed over 2000 homes, caused $\$ 4$ billion of damages (O’Neill and Handmer 2012), and contributed to widespread impacts on mental health and relationships in affected areas (Bryant et al. 2014).

This event triggered a period of significant policy transition as actors within the SES responded to this disruption (Fig. 3). A Royal Commission into Victoria's Bushfires (2010) recommended significant changes to bushfire management in Victoria. In response, DELWP developed a Code of Practice for Managing Bushfire Risk on Public Land that set objectives to protect multiple value categories including human life and property, infrastructure, public administration, environment, economy, and social setting (PIPESS), with protection of human life prioritized over all else (Department of Sustainability and Environment 2012). Between 2009 and 2015, DELWP also worked to meet hectare-based planned burning targets set by the Royal Commission. Planned burning - the controlled use of fire to reduce fuel loads - is the main risk-mitigation strategy used on public land in Victoria. However, frequent burning can negatively 
Fig. 3. Timeline of key events relating to bushfire management governance adaptation, Victoria 2009-2018, in relation to phases of the collaborative research project.

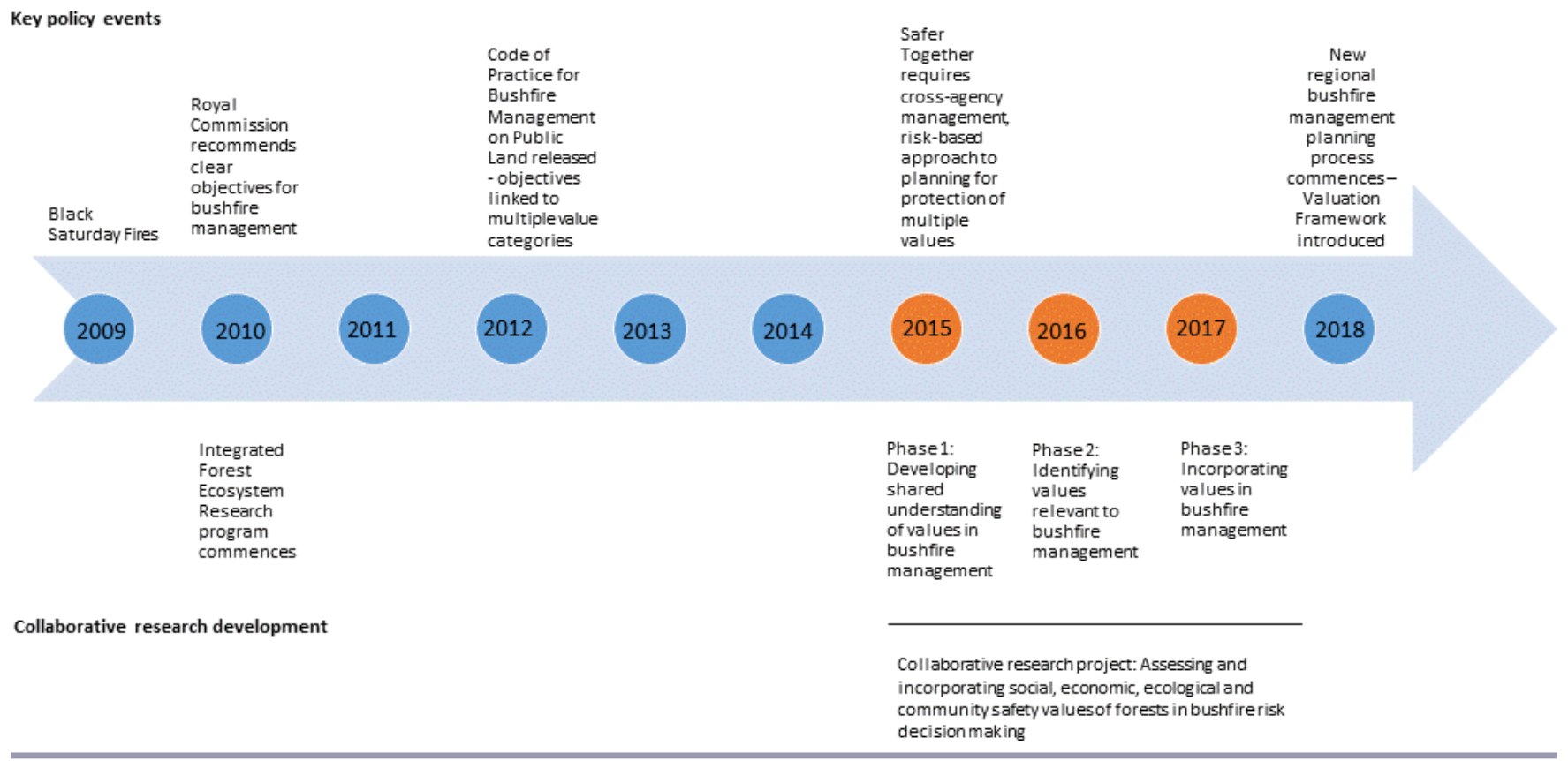

impact ecosystems, and the increased use of planned burning soon led to scientific and public concern that the planned burning targets meant an unacceptable balance between environment and human life values (Ford et al. 2019). By 2015, there was further policy change, from the hectare-based target for planned burning to a "risk-based approach" guided by the "Safer Together" policy (The State of Victoria 2015). Safer Together committed the State to cross-agency strategic planning, fuel management targeting risk to assets, and greater attention to community values and participation in bushfire management.

\section{Case Study: Collaborative Research on Values and Bushfire}

The events described above led to the establishment of the collaborative research described in this paper. One area of improvement targeted by DELWP was to understand values of the public and explicitly incorporate them in their decision making (The State of Victoria 2015). Between 2015 and 2017, DELWP sought input from our research team on how to achieve this. The social research was embedded within a long-term multidisciplinary Integrated Forest and Ecosystem Research (IFER) program, a collaboration between the University of Melbourne and DELWP that has supported applied research over more than 10 years. Within IFER, researchers work closely with DELWP policy leaders to identify knowledge needs and undertake research that is of international significance and can support policy and management development within DELWP. The research project considered within this paper ("Assessing and incorporating social, economic, ecological and community safety values of forests in bushfire risk decision making") consisted of several studies and involved collaboration with many planning and community engagement staff with responsibility for statewide guidance on bushfire planning, and with regional staff responsible for developing and implementing regional bushfire risk management plans.

\section{Observations}

To assess how the collaborative research supported social learning to incorporate values of the public in bushfire governance, we drew on data from the collaborative research process, including research publications, unpublished internal reports, and researcher notes from meetings and workshops. Specific sites of observation are listed below:

- initial meetings to codesign the project, in which the DELWP policy leader articulated policy questions, and the researchers worked with them to translate these into research questions and a written project plan;

- regular meetings between researchers and the policy leader to discuss planning of studies and broader engagement with DELWP staff;

- colocation of a researcher in the DELWP offices one day a week over much of the life of the project to facilitate informal mutual understanding;

- interviews with 13 DELWP policy and operational staff to understand how values were currently managed in the planning process (Ford et al. 2019);

- codevelopment of three workshops with members of the public, designed to develop participatory value-based scenarios of bushfire management (Rawluk et al. 2018);

- codesign, conduct, and reporting of two action research studies with the goal of developing practical strategies to incorporate values in bushfire decision making (Rawluk et al. 2020b); 
Fig. 4. Summary of research collaboration across 2015-2017, indicating broad goals, collaborative practices, and guiding questions.

\begin{tabular}{|c|c|c|c|}
\hline Broad goal & $\begin{array}{l}\text { Developing a shared } \\
\text { understanding of how } \\
\text { values figure in bushfire } \\
\text { planning }\end{array}$ & $\begin{array}{l}\text { Identifying values } \\
\text { relevant to bushfire SES } \\
\text { governance }\end{array}$ & $\begin{array}{l}\text { Incorporating values in } \\
\text { bushfire management }\end{array}$ \\
\hline $\begin{array}{l}\text { Collaborative } \\
\text { practices }\end{array}$ & $\begin{array}{c}\text { Phase } \begin{array}{c}\begin{array}{l}\text { Joint concept } \\
\text { development }\end{array} \\
1\end{array} \begin{array}{c}\text { Practice } \\
\text { analysis }\end{array}\end{array}$ & $\begin{array}{ll}\text { lase } & \begin{array}{l}\text { Knowledge } \\
\text { sharing } \\
2\end{array} \\
\cdot \text { Colocation }\end{array}$ & $\begin{array}{l}\text { - Codesign } \\
\text { - Action } \\
\text { research }\end{array}$ \\
\hline $\begin{array}{l}\text { Guiding } \\
\text { questions }\end{array}$ & $\begin{array}{l}\text { How do values figure in bushfire } \\
\text { governance? } \\
\text { How can values be best } \\
\text { understood in bushfire } \\
\text { governance? }\end{array}$ & $\begin{array}{l}\text { What specific values of the public } \\
\text { can be affected by bushfire } \\
\text { management? } \\
\text { How do bushfire management } \\
\text { actions relate to values of the } \\
\text { public? }\end{array}$ & $\begin{array}{l}\text { How can values of the public be } \\
\text { practically incorporated in } \\
\text { bushfire decision making, } \\
\text { including through: } \\
\text { - community engagement, and } \\
\text { - strategic planning? }\end{array}$ \\
\hline
\end{tabular}

- nine workshops involving more than 50 DELWP staff to develop shared understanding of value concepts, findings, and opportunities for incorporating knowledge in practice; and

- meetings and emails with a reference group of four DELWP community engagement staff to develop and gain input on a summative document for internal DELWP use titled "Strategies and tools for incorporating values of the public in bushfire risk management."

\section{Analysis}

We first drew on these data to construct a narrative account of how the collaborative research proceeded over time, highlighting collaborative processes (including actors, objectives, and practices), learning, and knowledge production (including insights to values and how they could be managed). We then assessed the narrative through the conceptual framework outlined above, considering (1) surprises or interruptions (van Herk et al. 2011, Rawluk et al. 2020a), (2) evidence of related sense making and single-, double-, and triple-loop learning (Pahl-Wostl 2009, Dwyer and Hardy 2015), and (3) aspects of the research collaboration that constrained learning, including collaborative practices (Ayre et al. 2018) and organizational assumptions about values or bushfire governance that might stabilize practice (Rawluk et al. 2019, Bosomworth 2015).

\section{LEARNING TO MANAGE VALUES IN VICTORIAN BUSHFIRE RISK PLANNING}

Figure 4 summarizes the collaborative research process, which occurred across three interrelated and overlapping phases: establishing shared understanding; identifying values relevant to the bushfire management; and incorporating values in bushfire management. Table 1 summarizes how the collaborative research supported learning, identifying points of disruption and related sense making, learning, and constraints on learning. The collaborative research and associated learning summarized in these materials are discussed in detail in this section.

\section{Phase 1: Developing a Shared Understanding of How Values Figure in Bushfire Planning}

Identifying how values figure in existing bushfire governance Despite a year of codeveloping a project plan with the DELWP policy leader, the research collaboration began with a surprise. The plan specified that in the second year of the project researchers would conduct a "desk top study evaluating existing frameworks and indicators for bushfire risk decision making." The policy leader instead urged us (the researchers) to tackle this task first and to reframe it to more broadly consider the existing policies and practices within bushfire governance and management. This was not a priority for us, as following our usual research practice, we wanted to first develop a shared understanding of values that could guide the project. Somewhat reluctantly, we worked with the policy leader to develop a study that would give us working knowledge of DELWP policy and practices while also providing new academic knowledge of how values were explicitly and implicitly managed in existing bushfire risk decision making. We used document analysis, interviews, and workshops to explore how values were handled across priority setting, analysis, and moving to decisions in bushfire governance (Ford et al. 2019). The analysis highlighted preferences within the agency for working with measurable or spatially locatable values, which meant some values were managed "in" or "out" of decision making in ways that were rarely made explicit (see also Neale 2016). While there was some move toward more transparent and structured forms of working with values (e.g., drawing on structured deicsion making (Gregory et al. 2012)) and some examples of community-based fire management that could incorporate values in more discursive ways, these approaches were far from common (Ford et al. 2019). 
Table 1. Examples of how a 3-year collaborative research program supported social learning about incorporating values in bushfire governance

\begin{tabular}{|c|c|c|c|c|c|c|}
\hline $\begin{array}{l}\text { Project } \\
\text { component }\end{array}$ & $\begin{array}{l}\text { Interruptions that } \\
\text { triggered learning }\end{array}$ & Sense making & $\begin{array}{l}\text { Single-loop learning } \\
\text { (incremental change to } \\
\text { routines) }\end{array}$ & $\begin{array}{l}\text { Double-loop learning } \\
\text { (reframing values and } \\
\text { goals) }\end{array}$ & $\begin{array}{l}\text { Triple-loop learning } \\
\text { (transformation) }\end{array}$ & Constraints on learning \\
\hline \multirow[t]{2}{*}{ Phase 1} & $\begin{array}{l}\text { - Questioning of } \\
\text { research plan to } \\
\text { undertake "light } \\
\text { touch" study of } \\
\text { existing practice in } \\
\text { later part of project }\end{array}$ & $\begin{array}{l}\text { - Practical } \\
\text { understanding of how } \\
\text { values figure in } \\
\text { bushfire governance }\end{array}$ & $\begin{array}{l}\text { - Tailoring concepts } \\
\text { and language around } \\
\text { values to } \\
\text { understanding of } \\
\text { bushfire governance }\end{array}$ & $\begin{array}{l}\text { - More realistic } \\
\text { expectations of how } \\
\text { practice might change } \\
\text { to include values }\end{array}$ & $\begin{array}{l}\text { - Changed research } \\
\text { practice: grounding in } \\
\text { analysis of existing } \\
\text { SES decision making }\end{array}$ & \\
\hline & $\begin{array}{l}\text { - Joint conceptual } \\
\text { development of } \\
\text { framework describing } \\
\text { role of values in SES } \\
\text { governance }\end{array}$ & & $\begin{array}{l}\text { - New and shared } \\
\text { definitions of concepts } \\
\text { relevant to values in } \\
\text { bushfire governance }\end{array}$ & $\begin{array}{l}\text { - Reinterpretation and } \\
\text { articulation of } \\
\text { bushfire management } \\
\text { around concept of } \\
\text { values }\end{array}$ & & $\begin{array}{l}\text { - Perceived lack of } \\
\text { relevance of concepts (e.g., } \\
\text { core values) to governance. } \\
\text { - Learning differs across } \\
\text { core agency collaborators } \\
\text { and regional staff }\end{array}$ \\
\hline \multirow[t]{3}{*}{ Phase 2} & $\begin{array}{l}\text { - Tension within } \\
\text { research collaboration } \\
\text { regarding reporting of } \\
\text { results }\end{array}$ & $\begin{array}{l}\text { - Insights to } \\
\text { importance of strong } \\
\text { collaboration to } \\
\text { maintain shared } \\
\text { understanding }\end{array}$ & & & $\begin{array}{l}\text { - Changed research } \\
\text { practice: colocation of } \\
\text { researcher in agency }\end{array}$ & \\
\hline & $\begin{array}{l}\text { - Sharing of new data } \\
\text { describing values } \\
\text { relevant to bushfire } \\
\text { and its management }\end{array}$ & $\begin{array}{l}\text { - Understanding of } \\
\text { why and how "assets" } \\
\text { or valued entities } \\
\text { matter to members of } \\
\text { public and in decision } \\
\text { making }\end{array}$ & $\begin{array}{l}\text { - Identifying a broader } \\
\text { range of values } \\
\text { relevant to objective } \\
\text { setting and analysis in } \\
\text { bushfire management }\end{array}$ & & & $\begin{array}{l}\text { - Lack of data/knowledge } \\
\text { about some values } \\
\text { - Concerns about "raising } \\
\text { expectations" or balancing } \\
\text { public values with } \\
\text { institutional requirements }\end{array}$ \\
\hline & $\begin{array}{l}\text { Development and } \\
\text { presentation of value- } \\
\text { based scenarios }\end{array}$ & $\begin{array}{l}\text { - Recognizing diverse } \\
\text { community } \\
\text { perspectives on } \\
\text { bushfire management }\end{array}$ & & & & $\begin{array}{l}\text { - Perceived relevance of } \\
\text { core values to bushfire } \\
\text { governance } \\
\text { - Problem framing that } \\
\text { limits attention to small } \\
\text { number of management } \\
\text { actions } \\
\text { - Existing technical } \\
\text { knowledge may contribute } \\
\text { to discounting of } \\
\text { community views }\end{array}$ \\
\hline \multirow[t]{2}{*}{ Phase 3} & $\begin{array}{l}\text { - Collective idea } \\
\text { generation about } \\
\text { application of findings } \\
\text { to practice }\end{array}$ & & $\begin{array}{l}\text { - Structuring objective } \\
\text { and analysis around } \\
\text { values of the public }\end{array}$ & $\begin{array}{l}\text { - Appreciating role of } \\
\text { community } \\
\text { engagement in } \\
\text { understanding values } \\
\text { of public }\end{array}$ & $\begin{array}{l}\text { - Broadening } \\
\text { organizational } \\
\text { expertise to work } \\
\text { better with diverse } \\
\text { values }\end{array}$ & \\
\hline & $\begin{array}{l}\text { - Action research to } \\
\text { develop ways to } \\
\text { incorporate values in } \\
\text { decision making }\end{array}$ & $\begin{array}{l}\text { - Adapting research } \\
\text { concepts to fit to } \\
\text { decision-making } \\
\text { context }\end{array}$ & $\begin{array}{l}\text { - Specifying broader } \\
\text { values that will be } \\
\text { considered in bushfire } \\
\text { management } \\
\text { - Developing } \\
\text { questions to } \\
\text { encourage reflection in } \\
\text { analysis of risk }\end{array}$ & $\begin{array}{l}\text { - Reframing } \\
\text { community } \\
\text { engagement practice } \\
\text { as a process of } \\
\text { listening to and } \\
\text { documenting values of } \\
\text { public/communities } \\
\text { - Encouraging use of } \\
\text { qualitative } \\
\text { information in } \\
\text { decision making }\end{array}$ & $\begin{array}{l}\text { - Intention to build } \\
\text { expertise in social } \\
\text { analysis }\end{array}$ & $\begin{array}{l}\text { - Limited expertise in social } \\
\text { assessment } \\
\text { - Limited knowledge about } \\
\text { some value categories and } \\
\text { how these relate to } \\
\text { management actions }\end{array}$ \\
\hline
\end{tabular}

Reflecting on "how" the collaborative research contributed to learning (Table 1), we noted that the policy leader's questioning of plans for the collaboration interrupted assumptions and routines-in this case, our own research routines. This interruption was fruitful in enabling new practical understanding (sense making) of how values figure in bushfire governance. Based on the observation of existing practices described above (Ford et al. 2019), we were able to assess how the agency talked about and managed values (intentionally or otherwise) in different parts of the organization. We also began to appreciate factors that shaped these approaches, for example, standardized risk assessment routines and institutional expertise grounded in ecological sciences. This allowed us as researchers to tailor concepts and language for DELWP collaborators and to form more realistic expectations of the ways of incorporating values that might be feasible within this context (single-loop learning). These insights established the basis for transforming some aspects of our practice (double- and triple-loop learning). For example, we developed new (to us) collaborative research approaches that centered on a deep understanding of our research partners' practices.

\section{Developing a shared conceptual framework}

As environmental social scientists working in an interdisciplinary setting, we were acutely aware of the different meanings ascribed to the term "values," and the need to establish a shared 
understanding early in the project. Through literature review, meetings with the DELWP policy leader, and drawing on insights to existing practice (Ford et al. 2019), we developed an interdisciplinary framework that identified relevant value concepts and related these to bushfire planning concepts such as objectives and assets (Rawluk et al. 2017). We developed this approach to accommodate multiple concepts of value, bridging psychological conceptions of "core values" as abstract principles (Schwartz et al. 2012), ideas from natural resource management that understand "valued attributes" as important qualities of landscapes (Kendal et al. 2015), and drawing on place (Beilin and Reid 2015) as a "valued entity" that is spatially locatable. In representing a process by which people value landscape properties, we bridged social properties of the SES (such as ideas and principles) with ecological properties (such as attributes and entities that were valued by people). We also connected academic representations of values with the multiple ways that values figured in bushfire planning: core values paralleled DELWP's broad strategic objectives such as valuing human life over all else (Department of Sustainability and Environment 2012); valued attributes of landscapes and communities mirrored the categories of objectives that were used to structure planning (e.g., the PIPESS framework); and valued entities were related to the locatable "assets" in the landscape targeted for protection in bushfire planning (Rawluk et al. 2019).

This bridging framework was shared and explored with DELWP policy and operational staff at a 2015 workshop involving approximately 30 participants. Notes from that workshop indicate that many of the concepts resonated with DELWP staff, but that core values were considered difficult to understand and less relevant to their work. They also noted that the (descriptive) framework could not answer complex questions posed by participants, such as how to balance contested values, or how to work with changing values in society. This feedback highlighted how learning occurred differently across the agency and collaborators (Table 1). For researchers, the policy leader and some other DELWP staff, joint conceptual development resulted in development of new and shared terms for concepts used within existing routines (single-loop learning) and paved the way for changes in both research and practice in later phases of the collaboration (triple-loop learning, for example, the Valuation Framework described in Phase 3). For regional staff, learning was less clear, although the workshop raised questions that may have supported later sense making and learning.

\section{Phase 2: Identifying Values Relevant to Bushfire SES Governance}

Identifying values of the Victorian public that can be affected by bushfire and bushfire management

When we commenced research, objectives for bushfire management in Victoria were defined by the Code of Practice for Bushfire Management on Public Land (Department of Sustainability and Environment 2012), including the PIPESS objective categories establishing that management should minimize risk to people, infrastructure, public administration, environment, economy, and social setting. The origin of these categories was not clear, some were not well defined (e.g., social setting), and there was no understanding of how the categories related to values of the Victorian public (Ford et al. 2019). The DELWP staff asked us to conduct research into values that were important to members of the Victorian public that could inform further development of the PIPE\$S categories. We used document analysis of public submissions to the Royal Commission into the Black Saturday fires alongside indepth interviews with 30 residents of areas at risk of bushfire to understand the range of values that they considered could be affected by bushfire and its management (Rawluk et al. 2017). These processes identified a range of relevant core values (e.g., benevolence and biospheric values), valued attributes (e.g., natural values of landscape and sense of normality in everyday life), and valued entities (e.g., homes, infrastructure, and natural places). Building on the qualitative analysis, we surveyed around 900 members of the public to refine categories of values and understand the relationships between the different levels of abstraction (Williams et al. 2018). Using structured equation modeling, we were able to reveal "pathways of valuing" that illuminated how ideals for what is important in life (core values) give importance to specific entities, including locatable objects and places (Williams et al. 2018). For example, protection of infrastructure was important to members of the public because it supported livelihood, production, and sense of normality and, through these, security.

During much of Phase 2, the researchers largely worked independently of DELWP staff. Difficulties arose in the collaboration through this period, with tensions focusing on the content of an internal milestone report: policy leaders were concerned that academic language and assumptions in the report were problematic for the DELWP audience and requested many changes that were time consuming to deliver. For researchers, the experience highlighted the risks of weaker collaboration occurring during a period focused on data collection by the researchers alone (sense making). As a result, we determined that one researcher should work in DELWP offices one day a week during this period to facilitate more informal information sharing, an arrangement that continued for the remainder of the collaborative project (triple-loop learning).

We presented preliminary research findings to DELWP staff at four workshops conducted in 2016. At these workshops, researchers explained the diversity of values observed within the Victorian public, emphasizing how these were similar and different from the PIPE\$S categories, and how core values help us to understand why some places or objects in the landscape are important to people. A common response to the research from DELWP regional staff was that findings helped them understand "why assets matter" (sense making). For example, a DELWP staff member described how fire suppression on rural properties commonly targeted farmhouses, resulting in criticism for saving houses but not fences or livestock. The research findings helped them articulate how properties matter for livelihoods as well as human lives. Following the workshops, we saw how the research findings allowed multiple incremental changes to existing practices. For example, specifying a broader range of values affected by bushfire and bushfire management helped DELWP staff identify a broader range of values to consider in planning processes (single-loop learning). But concerns raised at the workshops also revealed constraints on learning. Some regional staff were concerned that lack of data regarding some values (e.g., experience of nature) meant the findings were not of practical use to them. Others felt the research findings would raise unrealistic expectations from the public that individual views would be accommodated in decision making. These staff described 
"nonnegotiables" of agency responsibilities, generally referring to legislative requirements to protect human lives "above all else," while meeting formal environmental protection obligations (Department of Sustainability and Environment 2012:1).

\section{Exploring how values can shape management actions}

Responding to the challenge posed above, we (researchers) proposed a second way to understand the role of values in bushfire management: to develop multiple scenarios for bushfire management that represented different balances of values, and to test public preferences for these scenarios. We judged that this approach would resonate with DELWP staff involved in practical regional planning as they often use scenarios to understand ecological outcomes and risk associated with management actions. We used a participatory process to develop creative, narrative, value-based scenarios that explored how residents of a bushfire-prone area understood how management actions relate to core values of concern to the public (Rawluk et al. 2018). Participatory scenarios were qualitatively developed through three workshops involving 11 members of the public with an interest in fire management. Three DELWP staff contributed to these workshops, primarily to clarify fire management concepts and learn from members of the public. Using a scenario matrix, we structured the scenario development around core values, asking participants to develop scenarios that variously prioritized principles of biospheric welfare, human welfare, self-direction, and security. Key insights were that members of the public were interested in a much wider range of management actions than DELWP planners, and linked values to management actions in interesting ways. For example, participants saw the core value of self-direction as being supported by community education, whereas security was supported by management actions such as limiting housing development in fire-prone areas.

We presented these scenarios to DELWP policy and operational staff in workshops conducted in 2016. The response to the scenarios was initially positive. They saw the scenarios as recognizable views on bushfire management they had observed within communities. Some community engagement staff wondered if the scenarios might provide a conversation starter for exploring values in the community. Regional planning staff suggested the scenarios be used as the basis for an internal reflection among DELWP planning teams as they deliberated on the design and selection of regional strategies. However, we saw no such changes in DELWP practices following these discussions. Reflecting on this, we suggest several possible reasons: (1) the scenarios foregrounded core values that DELWP staff had indicated were less relevant to their work than more tangible valued attributes and entities; (2) the scenarios developed by members of the public involved many fire management actions (such as evacuation) that were well beyond DELWP regional focus on fuel reduction; and (3) some DELWP staff members were critical of the technical accuracy of the scenarios, for example, citing their technical understanding that fire risk could not be reduced through community education.

\section{Phase 3: Incorporating Values in Bushfire Management}

Identifying potential changes to bushfire governance During workshops conducted in 2016 and 2017, we explored with DELWP staff how the research findings from Phases 1 and 2 could be useful to them. The DELWP staff reflections ranged from ways the research generally illuminated their own experiences through to how it could inform very practical tools to support decision making. The researchers collated and added to these ideas (summarized in Table 2) and presented these to DELWP staff in the draft internal document, "Strategies and tools for incorporating values of the public in bushfire risk management." The full list contained many potential changes to management, primarily ones involving incremental changes (single-loop learning) to existing routines, for example, structuring decisions around value-based objectives. Some more transformational changes were also suggested (triple-loop learning), for example, broadening organization expertise.

Based on these ideas, the researchers and the DELWP policy leader identified two action research case studies. These case studies provided an opportunity to further develop and test some strategies for incorporating values of the public in bushfire decision making.

\section{Case studies for integrating values in community engagement practice and strategic planning}

One case study focused on how the research might inform community engagement practices. Community engagement specialists from DELWP identified the need for tools to understand what values are important at a local scale (Rawluk et al. 2020b). They worked with a researcher to develop an interactive workshop method involving participatory mapping to better understand what matters to a local community. Linked to this, they developed ways to collate and quantify expressed values in a way they considered useful for informing regional-level planning processes. The community engagement specialists described this focus on better listening to communities as a "radical" reframing of their work (double-loop learning) as existing expectations of community engagement specialists emphasized knowledge provision from DELWP to community members. The case study also revealed that whereas community engagement staff saw great potential in using engagement activities to collect data about community values, they were not confident in collecting, documenting, organizing, and reporting such data. As a result, the manager of the DELWP community engagement team sought opportunities for capacity building in social assessment, including through a new collaborative research project we undertook with DELWP from 2018, suggesting evidence of triple-loop learning.

A second case study considered how the research findings could be applied in regional strategic planning to manage bushfire risk. The DELWP policy leader initiated the development of a "Valuation Framework" to guide risk assessment, and this became the focus of an action research case study (Rawluk et al. $2020 b$ ). Her goal was to provide a framework that would draw attention to the full breadth of values important to the public and support regional planners in assessing how these values might be affected by bushfire and by risk management strategies. She began by considering the range of valued attributes identified through our social research (Rawluk et al. 2017) and modified the expression of some values to fit better with the regional landscape scale of planning and the knowledge culture of DELWP. For example, people's concerns about livelihood were rearticulated in terms of regional economic values. She then combined the resulting set of valued attributes with additional agency criteria for assessing bushfire management, including cost and equity. 
Table 2. Potential approaches for incorporating values in bushfire risk planning in Victoria. Approaches were identified by DELWP staff and researchers through collaborative research conducted during 2015-2017. During workshops and meetings and document reviews, agency staff were asked to identify ways new knowledge about values could be practically applied in their work

\begin{tabular}{ll}
\hline \hline $\begin{array}{l}\text { Decision making points in bushfire } \\
\text { planning }\end{array}$ & Approaches suggested for incorporating values in planning \\
\hline Organizational expertise & $\begin{array}{l}\text { Develop a shared language for recognizing and talking about values } \\
\text { Enhance organizational capacity in disciplines with expertise in understanding, measuring, and incorporating } \\
\text { values in decision making }\end{array}$ \\
Identify values and priorities relevant to bushfire and its management through social analysis and community \\
engagement \\
Priority setting & Use participatory processes for value identification and objective setting, e.g., value-based conversations \\
& Explicitly link objectives to values and valued properties of landscape and communities \\
& Structure analysis in relation to selected values and objectives \\
Analysis of the effects of bushfire and & Identify links between management actions and valued properties of SES \\
its management on values & Develop metrics and qualitative indicators that reflect values of public and relevant ways of knowing \\
& Use participatory processes to develop key tools such as asset registers (e.g., participatory mapping) \\
& Develop and evaluate a set of alternative management options that reflect full range of value priorities \\
Moving to a decision & Use deliberative or structured approaches that explicitly evaluate options against values and objectives \\
& Design participatory processes to inform option selection (e.g., citizen juries) \\
& Develop value-based narratives to account for decisions
\end{tabular}

Next, she developed strategic questions that helped regional planning teams consider how these values might be related to landscape assets, or in other tangible ways be amenable to planning decisions, in part guided by the "pathways of valuing" described above. Finally, she developed questions to help regional staff explore how these valued attributes might be affected by bushfire and by management actions to mitigate these effects. The use of strategic questions was distinctive in its hope of enabling reflective and flexible application by regional planning teams, and by the potential it created to use more qualitative forms of data or explanation. Of note, the process engaged with more tangible forms of values identified through the collaborative research (valued attributes and entities), while the more abstract core values were not considered relevant.

The DELWP policy leader developed this framework over a period of about a year with the support of her supervisors. Yet for much of this time, it was not clear how the valuation framework would be used in decision making. In 2018, we learnt that it had been included as part of a new state-wide bushfire risk planning process. The planning process was significantly revised as part of the move toward risk-based fuel management described earlier. The team responsible for this transition designed the overall process in line with the principles of structured decision making (Gregory et al. 2012). They thought the Valuation Framework would help regional planning teams identify objectives as part of their landscape assessment. This adoption of the Valuation Framework (and with it the underpinning components of research) seemed almost serendipitous:

We had a first draft of the Technical Methods document and were reviewing that with some engagement with the regions. [The DELWP policy leader] approached us after a meeting and said "we have this Valuation Framework we've been working on. Can we pilot that with a region?" We offered to put it into the planning process. It seemed a good fit. We needed regions to do an environmental scan, and the Valuation Framework does that and more. (Interview with DELWP planning staff member, 27/3/2018.)

This case study primarily provides evidence of single-loop learning, through incremental changes to existing risk assessment processes by broadening and better specifying the range of values to be considered. In this form of learning, there was expansion on "what" was considered within the status quo approach. Some aspects of the case also indicate double-loop learning, questioning how practice is undertaken: the question-based approach encouraged DELWP regional staff to consider qualitative information alongside the spatially based and quantitative assessment that was in routine use.

\section{DISCUSSION}

Building on work of Rawluk et al. (2020a) and Dwyer and Hardy (2015), this exploration suggests collaborative research can support social learning through multiple forms of interruption: questioning of plans and routines (including of researchers), joint concept development, collection and sharing of new information, tensions within the research collaboration, idea generation building on research insights, and action research to develop new tools or frameworks. These forms of disruption operated in different ways, involving different groups of actors, levels of collaboration, and opportunities for feedback, and these in turn had implications for the forms of learning that occurred.

Interruptions differed in the range of people involved, and this appeared to shape how learning played out across the collaboration and agency. For example, questioning of research practices and tension within the research collaboration primarily involved researchers and the policy leader, whereas idea generation through workshops and action research case studies involved a wider range of actors. Pahl-Wostl (2009) has noted the complexity of learning that occurs within complex multiagency adaptive governance, and we observed a similar complexity - or unevenness - within a single organization that spanned many levels, regions, and areas of responsibility. Among core 
collaborators, including the policy leader, researchers, and staff involved in the action research case studies, there was considerable learning, including changes to collaborative research practices, reframing of roles such as community engagement, and decisions to build expertise in areas required to incorporate values in decision making. For DELWP regional planning teams, who were less closely involved in the research collaboration, learning was less evident. However, there were many examples of sense making among these actors, and it is reasonable to speculate that this may have set the scene for learning beyond the life of this research collaboration. Although van Herk and colleagues (2011) observed that collaborative research can influence policy transition through awareness raising and capacity building at the broader scale, our observations highlight the risk that social learning through collaborative research may be isolated within parts of an organization (Gherardi 2012). This has implications for design of collaborative research, reinforcing van Herk and colleagues' (2011) assertion that that actors within a research collaboration should be widely connected and highly communicative in approach.

The forms of interruption providing clearest evidence of multiloop learning involved high levels of collaboration and opportunities for feedback. Collaborative processes occurring in Phase 3 of the project - idea generation and action research case studies - involved significant investment of time by researchers and agency staff and appeared to be especially potent forms of learning. For example, the community engagement case study triggered reframing of roles and responsibilities for those directly involved (double-loop learning) and a decision to build relevant capacity among community engagement staff (triple-loop learning). Interruptions in the form of new data on values (Phase 2) involved less intense collaboration among researchers and practitioners and appeared to initiate less direct evidence of learning. Although this demonstrates the value of more collaborative activities, it should not be interpreted as suggesting researcher-led data collection and analysis have lesser value. The action research case studies could not have been undertaken without knowledge developed through earlier steps of conceptual development and data collection. Furthermore, we found (as have others, e.g., Ayre et al. 2018) that activities involving high levels of direct collaboration were difficult to organize and dependent on windows of opportunities that were hard to identify (Rawluk et al. 2020b). A more appropriate interpretation of this finding is that a range of forms of collaboration are needed to support learning to incorporate values in SES governance, and that collaborative research programs should be designed to enable these, ensuring scope for feedback to support multiloop learning.

The analysis identified constraints on learning including lack of knowledge and data about some values, perceived lack of relevance of some knowledge to work of the agency, limitations in expertise of agency staff, and constraints linked to framing of roles and responsibilities within bushfire planning. Across these constraints, we observed two general patterns that could assist others seeking to incorporate values in SES governance.

First, we anticipated that the dominant scientific-technical expertise of agency staff would result in some challenges as staff grappled with values conceptualized through social research. We did observe this pattern but in an unexpected way: while the research revealed many opportunities for incorporating an understanding of valued attributes and entities in bushfire planning, knowledge of core values was largely excluded from consideration. Early in the project, we observed that regional staff saw core values as less relevant to their work because they were considered too abstract to manage, and DELWP staff involved in both action research case studies focused on valued attributes and entities as they developed new tools and frameworks. We consider this problematic. Core values of security and self-direction underpin public preferences for the role of government and individuals in bushfire governance (Rawluk et al. 2018), and so are highly relevant to acceptance of bushfire governance principles such as "shared responsibility" (The State of Victoria 2015) and management strategies that may impact on individual freedom, such as evacuation or cultural burning practices. Although there has been some effort to communicate the relevance of core or "transcendent" values to SES governance (e.g., Raymond and Kenter 2016), further work is needed to ensure clear links to policy and practice.

Second, the analysis revealed many factors that constrained learning, but also illustrates how the very uncovering of these constraints through collaborative research serves as a form of social learning. Many of the constraints noted in Table 1 share a common origin: the dominance of an "emergency management" framing of bushfire governance in Victoria, in which bushfire management is approached as a technical problem of managing fuel loads, and relationships with members of the public are viewed primarily in terms of educating people about risk (Bosomworth 2015). Pahl-Wostl (2009) notes that such narratives can stabilize and restrict practices that might enable more adaptive governance, but also lists the questioning of such assumptions as an example of double-loop learning. We observed this intertwining of constraint and learning as community engagement staff grappled with the role of values in their own work, for example, in the "radical" reframing of community engagement as education to community engagement as a form of listening. This learning set the scene for anticipated transformation within community engagement through expanding capacity in social analysis. Further longitudinal collaborative research may reveal whether this transformation occurs, how it influences the practices in other (potentially more powerful) parts of the organization, and how effectively it can challenge the dominant framing of bushfire governance (Rawluk et al. 2020b).

\section{CONCLUSION}

So how does collaborative research support social learning to incorporate values of the public in bushfire governance? This research confirms the usefulness of collaborative research to support social learning during policy transition (van Herk et al. 2011). Extending work by Pahl-Wostl (2009), van Herk et al. (2011), and Rawluk et al. (2020a), it shows how interruptions in the form of questions, new knowledge, tensions within the collaboration, and opportunities for joint reflection and action can trigger sense making and, in time, learning. Time is important in this regard. Policy transitions are not a linear or quick process and require different forms of collaboration at different times across long periods of time. We were able to sustain a high level of collaboration over an extended period due to the well-established and funded IFER program. However, the 3-year project observed did not allow scope to fully observe how feedback loops functioned 
or how uneven learning was either shared or isolated within parts of the organization. The findings therefore also reinforce the importance of long-term research programs for supporting learning through significant policy transitions (Redman et al. 2004).

Responses to this article can be read online at: https://www.ecologyandsociety.org/issues/responses. php/11987

\section{Acknowledgments:}

This project was funded by the Department of Environment, Land, Water and Planning (DELWP) in the State of Victoria. We are grateful to all DELWP staff who contributed to this research.

\section{Data Availability:}

The data that support the findings of this study are available on request from the corresponding author, $K W$. This insight paper synthesizes findings from existing publications (cited in manuscript - some publicly available, others not due to copyright restrictions) and draws on internal reports (unpublished as authored specifically for agency) and researcher notes (not publicly available as these contain information that could compromise the privacy of research participants).

\section{LITERATURE CITED}

Armitage, D., M. Marschke, and R. Plummer. 2008. Adaptive comanagement and the paradox of learning Global Environmental Change 18:86-98. https://doi.org/10.1016/j.gloenvcha.2007.07.002

Artelle, K. A., J. Stephenson, C. Bragg, J. A. Housty, W. G. Housty, M. Kawharu, and N. J. Turner. 2018. Values-led management: the guidance of place-based values in environmental relationships of the past, present, and future. Ecology and Society 23(3): 35. https:// doi.org/10.5751/ES-10357-230335

Ayre, M. L., P. J. Wallis, and K. A. Daniell. 2018. Learning from collaborative research on sustainably managing fresh water: implications for ethical research-practice engagement. Ecology and Society 23(1): 6. https://doi.org/10.1016/j.gloenvcha.2007.07.002

Beilin, R., and K. Reid. 2015. It's not a "thing" but a "place": reconceptualising "assets" in the context of fire risk landscapes. International Journal of Wildland Fire 24(1):130-137. https://doi. org/10.1071/wf14035

Bengston, D. N. 1994. Changing forest values and ecosystem management. Society and Natural Resources 7:515-533. https:// doi.org/10.1080/08941929409380885

Bosomworth, K. 2015. Climate change adaptation in public policy: frames, fire management, and frame reflection. Environment and Planning C: Government and Policy 33(6):14501466. https://doi.org/10.1177/0263774X15614138

Bryant, R. A., E. Waters, L. Gibbs, H. C. Gallagher, P. Pattison, D. Lusher, C. MacDougalls, L. Harms, K. Block, E. Snowdon,
V. Sinnotts, G. Ireton, J. Richardsons, and D. Forbes. 2014. Psychological outcomes following the Victorian Black Saturday bushfires. Australian and New Zealand Journal of Psychiatry 48 (7):634-643. https://doi.org/10.1177/0004867414534476

Chaffin, B. C., H. Gosnell, and B. A. Cosens. 2014. A decade of adaptive governance scholarship: synthesis and future directions. Ecology and Society 19(3): 56. https://doi.org/10.5751/ ES-06824-190356

Department of Sustainability and Environment. 2012. Code of practice for bushfire management on public land. State Government of Victoria,Melbourne, Australia.

Dwyer, G., and C. Hardy. 2015. We have not lived long enough: sensemaking and learning from bushfire in Australia. Management Learning 47:45-64. https://doi.org/10.1177/135050$\underline{7615577047}$

Ford, R. M., A. Rawluk, and K. J. H. Williams. 2019. Managing values in disaster planning: current strategies, challenges and opportunities for incorporating values of the public. Land Use Policy 81:131-142. https://doi.org/10.1016/j.landusepol.2018.10.029

Gherardi, S. 2012. Why do practices change and why do they persist? Models of explanations. Pages 217-231 in P. Hager, A. Lee, and A. Reich, editors. Practice, learning and change: practicetheory perspectives on professional learning. Springer, Dordrecht, The Netherlands. https://doi.org/10.1007/978-94-007-4774-6 14

Gregory, R., L. Failing, H. Harstone, G. Long, T. McDaniels, and D. Ohlson. 2012. Structured decision making. [electronic resource] : a practical guide to environmental management choices. Wiley, Chichester, UK; Hoboken, New Jersey, USA. https://doi. org/10.1002/9781444398557

Ives, C. D., and D. Kendal. 2014. The role of social values in the management of ecological systems. Journal of Environmental Management 144:67-72. https://doi.org/10.1016/j.jenvman.2014.05.013

Jones, N. A., S. Shaw, H. Ross, K. Witt and B. Pinner. 2016. The study of human values in understanding and managing socialecological systems. Ecology and Society 21(1): 15. https://doi. org/10.5751/ES-07977-210115

Kendal, D., R. M. Ford, N. M. Anderson, and A. Farrar. 2015. The VALS: a new tool to measure people's general valued attributes of landscapes. Journal of Environmental Management 163:224-233. https://doi.org/10.1016/j.jenvman.2015.08.017

Lindesay, J., and D.B. Lindenmayer. 2003. Fire and climate in Australia. Pages 32-40 inG. Cary, D. Lindenmayer, and S. Dovers, editors. Australia burning: fire ecology, policy and management issues. CSIRO Publishing, Clayton, Victoria, Australia. https:// doi.org/10.1071/9780643090965

Manfredo, M. J., J. T. Bruskotter, T. L. Teel, D. Fulton, S. H. Schwartz, R. Arlinghaus, S. Oishi, A. K. Uskul, K. Redford, S. Kitayama, and L. Sullivan. 2017. Why social values cannot be changed for the sake of conservation. Conservation Biology 31 (4):772-780. https://doi.org/10.1111/cobi.12855

Muir, C., J. Gilbert, R. O’Hara, L. Day, and S. Newstead. 2017. Physical bushfire preparation over time in Victoria, Australia. Disaster Prevention and Management 26(2):241-251. https://doi. org/10.1108/dpm-06-2016-0126 
Neale, T. 2016. Burning anticipation: wildfire, risk mitigation and simulation modelling in Victoria, Australia. Environment and Planning A 48:2026-2045. https://doi.org/10.1177/0308518X16651446

O'Brien, E. A. 2003. Human values and their importance to the development of forestry policy in Britain: a literature review. Forestry 76(1):3-17. https://doi.org/10.1093/forestry/76.1.3

O’Neill, S. J., and J. Handmer. 2012. Responding to bushfire risk: the need for transformative adaptation. Environmental Research Letters 7(1):014018. https://doi.org/10.1088/1748-9326/7/1/014018

Pahl-Wostl, C. 2009. A conceptual framework for analysing adaptive capacity and multi-level learning processes in resource governance regimes. Global Environmental Change 19:354-365. https://doi.org/10.1016/j.gloenvcha.2009.06.001

Raadgever, G. T., E. Mostert, and N. C. van de Giesen. 2012. Learning from collaborative research in water management practice. Water Resources Management 26:3251-3266. https:// doi.org/10.1007/s11269-012-0070-9

Rawluk, A., R. Ford, N. Anderson, and K. J. H. Williams. 2019. Exploring multiple dimensions of values and valuing: a conceptual framework for mapping and translating values for social-ecological research and practice. Sustainability Science 14:1187-1200. https://doi.org/10.1007/s11625-018-0639-1

Rawluk, A., R. Beilin, H. Bender, and R. Ford. 2020a. Practices in social ecological research: interdisciplinary collaboration in 'adaptive doing'. Palgrave Pivot, Cham, Switzerland. https://doi. org/10.1007/978-3-030-31189-6

Rawluk, A., R. Ford, S. Draper, L. Little, and K. J. H. Williams. 2020 b. Applying social research: how research knowledge is shaped and changed for use in a bushfire management organisation. Environmental Science and Policy 106:201-209. https://doi.org/10.1016/j.envsci.2020.01.021

Rawluk, A., R. M. Ford, F. L. Neolaka, and K. J. H. Williams. 2017. Public values for integration in natural disaster management and planning: a case study from Victoria, Australia. Journal of Environmental Management 185:11-20. https://doi. org/10.1016/j.jenvman.2016.10.052

Rawluk, A., R. M. Ford, and K. J. H. Williams. 2018. Value-based scenario planning: exploring multifaceted values in natural disaster planning and management. Ecology and Society 23(4): 2. https://doi.org/10.5751/ES-10447-230402

Raymond, C. M., and J. O. Kenter. 2016. Transcendental values and the valuation and management of ecosystem services. Ecosystem Services 21:241-257. https://doi.org/10.1016/j. ecoser.2016.07.018

Redman, C. L., J. M. Grove, and L. H. Kuby. 2004. Integrating social science into the long-term ecological research (LTER) network: social dimensions of ecological change and ecological dimensions of social change. Ecosystems 7:161-171. https://doi. org/10.1007/s10021-003-0215-Z

Reser, J. P., and J. M. Bentrupperbäumer. 2005. What and where are environmental values? Assessing the impacts of current diversity of use of "environmental" and "World Heritage" values.
Journal of Environmental Psychology 25(2):125-146. https://doi. org/10.1016/j.jenvp.2005.03.002

Royal Commission into Victoria's bushfires, B. G. Teague, R. N. McLeod, and S. M. Pascoe. 2010. 2009 Victorian Bushfires Royal Commission-final report, summary. State of Victoria, Melbourne, Australia

Schwartz, S. H., J. Cieciuch, M. Vecchione, E. Davidov, R. Fischer, C. Beierlein, A. Ramos, M. Verkasalo, J. E. Lonnqvist, K. Demirutku, O. Dirilen-Gumus, and M. Konty. 2012. Refining the theory of basic individual values. Journal of Personality and Social Psychology 103(4):663-688. https://doi.org/10.1037/a0029393

Steelman, T. 2016. U.S. wildfire governance as social-ecological problem. Ecology and Society 21(4): 3. https://doi.org/10.5751/ ES-08681-210403

Stewart, J. 2006. Value conflict and policy change. Review of Policy Research 23(1):183-195. https://doi.org/10.1057/9780230240759 3

Thacher, D., and M. Rein. 2004. Managing value conflict in public policy. Governance 17(4):457-486. https://doi.org/10.1111/ j.0952-1895.2004.00254.X

The State of Victoria. 2015. Safer together: a new approach to reducing the risk of bushfire in Victoria. State Government Victoria, Melbourne, Australia.

Tyrväinen, L., K. Mäkinen, and J. Schipperijn. 2007. Tools for mapping social values of urban woodlands and other green areas. Landscape and Urban Planning 79:5-19. https://doi.org/10.1016/ j.landurbplan.2006.03.003

van Herk, S., C. Zevenbergen, J. Rijke, and R. Ashley. 2011. Collaborative research to support transition towards integrating flood risk management in urban development. Journal of Flood Risk Management 4:306-317. https://doi.org/10.1111/

j.1753-318X.2011.01113.X

van Riper, C. J., A. Thiel, M. Penker, M. Braito, A. C. Landon, J. M. Thomsen, and C. M. Tucker. 2018. Incorporating multilevel values into the social-ecological systems framework. Ecology and Society 23(3): 25. https://doi.org/10.5751/ES-10047-230325

Weick, K. E. 1995. Sensemaking in organisations. Sage Publications, Thousand Oaks, California, USA.

Williams, K. J. H., R. M. Ford, and A. Rawluk. 2018. Values of the public at risk of wildfire and its management. International Journal of Wildland Fire 27:665-676. https://doi.org/10.1071/ WF18038

Williams, R., C. Wahren, A. Tolsma, G. Sanecki, W. Papst, B. Myers, K. McDougal, D. Heinze, and K. Green. 2008. Large fires in Australian alpine landscapes: their part in the historical fire regime and their impacts on alpine biodiversity. International Journal of Wildland Fire 17:793-808. https://doi.org/10.1071/ $\underline{\mathrm{WF} 07154}$ 